\title{
Covid-19 Salgınının Türkiye'nin Vergi Gelirleri Üzerine Etkisi
}

\author{
DOI: 10.26466/opus.931186
}

\author{
* \\ Hamza Erdoğdu* - Murat Demir** - Ridvan Önder *** \\ * Dr. Öğr. Üyesi, Harran Üniversitesi, Şanlıurfa/Türkiye \\ E-Posta: hamzaerdogdu@harran.edu.tr \\ ORCID: $\underline{0000-0002-5025-2367}$ \\ ** Prof. Dr., Harran Üniversitesi, Şanlıurfa/Türkiye \\ E-Posta: mdemir@harran.edu.tr \\ ORCID: $\underline{0000-0002-1466-1104}$ \\ *** Vergi Müfettişi, Dr. Öğr., Ankara Hacı Bayram Veli Üniversitesi, Ankara/Türkiye \\ E-Posta: ridvan.onder@vdk.gov.tr \\ ORCID: $\underline{0000-0003-0021-7771}$
}

Öz

Bu çalışma, 2019 yllnın son çeyreğinde Çin Halk Cumhuriyetinde ortaya çıkan ve tüm dünyayı etkisi altına alan Covid-19 salginının, Türkiye'de vergi gelirlerine olan etkisini analiz etmeyi amaçlamaktadır. Bunun için Türkiye'nin vergi gelirleri; ekonomik büyüme, enflasyon ve faiz oranlar gibi makro değgişkenlerin yanmnda, Covid-19 pandemisinden kaynaklanan ekonomik krizin etkisini dikkate almak için, bir kukla değişkenin de dahil edildiği bir model tarafindan 2006.M01-2021.M01 aralı̆̆ aylık verileri kullanılarak açıklanmaktadır. Çalışmada değiş̧kenler arasında bir uzun dönem ilişkisinin olup olmadığın sinamak için kullanılan doğrusal ARDL ile doğrusal olmayan ARDL yöntemlerine ilave olarak şoklarm modelde yer alan değişkenler üzerindeki etkilerinin belirlenmesi amacryla etki-tepki (impulse-response) fonksiyonlar ile varyans ayrıştırması (variance decomposition) yöntemleri kullanilmıştır. Hem doğrusal ARDL hem de doğrusal olmayan ARDL yöntemince desteklenen ilk ampirik sonuç, değişkenler arasında bir uzun dönem ilişkinin var olduğudur. İkinci olarak, Covid-19 küresel salgzn krizinin Türkiye'de vergi gelirlerini olumsuz etkilediği istatistiksel olarak gösterilmektedir. Pandemi koşullar, ülkelerin ekonomik büyüme oranlarını düşük olması nedeniyle vergi gelirlerinin de azalacağın göstermektedir.

Anahtar Kelimeler: Covid-19 Pandemi, Vergi Gelirleri, Kukla Değişken, ARDL, NARDL.

JEL Kodu: $\quad H 20, C 10, C 51, C 52$ 


\title{
Impact of the Covid-19 Outbreak on Turkey's Tax Revenues
}

\begin{abstract}
This study aims to analyze the epidemic Covid-19, emerging in the People's Republic of China in the last quarter of 2019 and influencing the whole world, effect on tax revenues in Turkey. For this tax revenue of Turkey is explained by a model with macro variables such as economic growth, inflation and interest rates, including a dummy variable to take into account the impact of the economic crisis caused by the Covid-19 pandemic, using monthly data on 2006.M01-2021.M01. In the study, in addition to linear ARDL and non-linear ARDL methods used to test whether there is a long-term relationship between variables, impulse-response functions and variance decomposition methods were used to determine the effects of shocks on the variables in the model. The first empirical result supported by both linear ARDL and nonlinear ARDL methods is that there is a long-term relationship between variables. Secondly, Covid-19 global outbreak crisis negatively affects tax revenues in Turkey is shown statistically. The conditions of the pandemic show that due to the low rates of economic growth of the countries, tax revenues will also decrease.
\end{abstract}

Keywords: $\quad$ Covid-19 Outbreak, Tax Revenues, Dummy Variable, ARDL, NARDL.

\section{JEL Classification}

Codes:

H20, C10, C51, C52 


\section{Giriş}

Dünya Bankası 2019 yılı sonunda Çin'de ortaya çıkan ve tüm dünyayı etkisi altına alan salgın hastalık nedeniyle küresel ölçekte GSYİH' daki küçülmenin yaklaşık \%5,2 olarak gerçekleşeceğini öngörmektedir Dünya Bankası 2020 yılında ortaya çıkan bu daralmayı, 1929 yılından sonra dünyada yaşanan en büyük ekonomik durgunluk olarak ifade etmektedir (World Bank, 2020, s. 3). Daralmanın nedenlerine bakıldığında; salgın hastalığın yayılımının önlenmesi amaciyla birçok ekonomik aktivitenin durdurulması ile tüketim ve yatırım harcamalarında ortaya çıan keskin düşüşlerin belirleyici olduğu görülmektedir. Hemen her sektörde giderek yaygınlaşan kısıtlamalar ve tüketim ve yatırım harcamalarının azalması ile birlikte işsizlik üzerinde de önemli baskılar yaratmıştır.

Maliye politikası ve araçları krizlerle mücadelede etkili politika araçlarıdır. Pandemi süreci bir yandan kamu gelirlerinin azalmasına neden olurken öte yandan kamu harcamalarında önemli artışlara yol açmıştır. Özellikle gelişmekte olan ülkelerde kamu finansman sorunlarının derinleşmesine neden olan bu gelişmeler maliye politikalarının hareket alanını ve etkinliğini de s1nırlandırmıştır. Bilindiği üzere ekonomik daralma dönemlerinde vergi gelirleri azalırken ekonominin genişleme dönemlerinde vergi gelirlerinde artış beklenir. Hiç kuşkusuz pandemi süreci de ekonomik ve mali yapıyı olumsuz etkilemekte alınan tedbirler, işyerlerinin kapanması, ulusal ve uluslararası ticaretin yavaşlaması ekonomik krize benzer etkiler yaratarak vergi gelirlerini doğrudan etkilemektedir.

Covid-19 salgını kısa sürede tüm dünyayı etkisi altına almış ve tüm ülkeleri derinden etkilemiştir. Bu kapsamda uluslararası ticaret durma noktasına gelmiş, tüm ülkeler ciddi ekonomik daralma ile karşı karşıya kalmıştır. Hükümetler pandeminin neden olduğu olumsuzlukların, ekonomik ve toplumsal krize dönüşmemesi için çeşitli önlemler almışlardır. Birçok ülkede ağırlıklı olarak maliye politikaları temelinde şekillenen önlemlere bakıldığında transfer harcamalarında artışlar olduğu, vergi ertelemeleri ve sektörel vergi indirimleri ile durgunluğun ve daralmanın hafifletilmeye çalışıldığı görülmektedir. Dünya Bankası verilerine göre; gelişmekte olan ülkelerin açıkladığı destek paketleri GSYİH'lerinin \%5,4-\%10'u arasındadır. Avro bölgesinde bu destekler GSIYH'in ortalama \%2.6'sı düzeyinde gerçekleşirken Almanya'da \%4,5'i, İtalya' da \%4'ü olarak gerçekleşmiştir. (World Bank, 2020, s.4). 
Bu çalışmada Türkiye' de vergi gelirlerinin küresel düzeyde 2020 yılı Mart ayından itibaren etkili olan Covid-19 pandemi sürecinden nasıl etkilendiği incelenmiştir. Çalışmanın gerçekleştiği tarih itibariyle eldeki mevcut veriler dikkate alınarak 2006.M01-2021.M01 dönemi için doğrusal olmayan ARDL (NARDL) doğrusal ARDL metodolojileri uygulanmıştır. Söz konusu çalışma ile literatüre üç farklı alanda katkı sunulması hedeflenmektedir. Öncelikle çalışma, Türkiye' de yapılan bilimsel çalışmalarda Covid-19 pandemisi etkisinin varlığını (test sayısı, vaka sayısı, hasta sayısı, vefat sayısı vb. değişkenleri modellemede kullanmaksızın) ekonometrik olarak gösterdiği için öncü nitelik taşımaktadır. İkincisi, Covid-19 pandemisinin spesifik olarak Türkiye'de vergi gelirlerine etkisinin istatistiksel olarak ortaya konmasıdır. Üçüncü olarak vergi gelirleri ile ekonomik büyüme, enflasyon ve faiz oranları arasındaki ilişki Covid-19 pandemisinin etkisi de dikkate alınarak hem doğrusal ARDL hem de ilişkinin asimetrik olduğu varsayımı ile doğrusal olmayan ARDL yaklaşımı ile analiz edilmiştir.

Çalışmanın ikinci bölümünde vergi gelirleri ile GSYİH ilişkisini teorik çerçevesi çizilip literatür özeti sunulmaktadır. Üçüncü bölümde çalışmada kullanılan veriler ve oluşturulan model ile yöntemlere yer verilmiştir. Dördüncü bölümde ampirik çalışma bulguları tablolar ve grafikler şeklinde verilmektedir. Son bölümde ise sonuç ve değerlendirmeler yer almaktadır.

\section{GSYİH ve Vergi Gelirleri İlişkisi}

Gelişmiş ve gelişmekte olan ülkelerin bütçe gelirlerinin yaklaşık \%80-95'ini oluşturan vergi gelirleri, en önemli maliye politikası araçlarından biridir. Verginin ilk ve öncelikli hedefi mali amaç olmasına rağmen son yüzyılda gelişen olayların etkisiyle verginin mali olmayan amaçları da kabul görmüş ve sıklıkla kullanılır hale gelmiştir. Verginin fiskal olmayan amaçları içerisinde yer alan konjonktür politikasına ilişkin amacı; ekonomide ortaya çıkan dönemsel nitelikli gelişmelere karşı vergiler aracılığıyla önlem alınmasını ifade etmektedir. Klasikler açısından vergilerin tarafsız olması ve bütçe denkliği ilkesinden sapılmaması adına, vergi gelirlerinin azaldığı ve/veya bütçe gelirlerinin azaldığı dönemlerde, minimal devletin giderlerini karşılamak üzere ekstra vergi konularak veya vergi oranları artırılarak bütçenin denkleştirilmesi gerektiği savunulmaktadır. Ancak 1929 yılında yaşanan buhranla ortaya çıkan 
Keynesyen iktisadi görüş ise tam aksi yöndedir. Kriz dönemlerinde kamunun bütçe denkliğini sağlamaya çalışması krizi daha da derinleştirebilir. Bu açıdan krize yönelik olarak karşı önlemler alınması gerektiği savunulmaktadir (Turhan, 2020, s.37-41).

Covid-19 salgın hastalığında görüldüğü gibi pandemi dönemleri de bir dizi ekonomik sorunu bünyesinde taşıarak her zaman bir ekonomik kriz üretme potansiyeline sahip bulunmaktadır. Hem reel sektör üzerinde hem de finans sektörü üzerinde ağır baskılar yaratan pandemi süreci tüm ekonomilerde ciddi düzeyde daralmalara yol açarak işsizlik oranlarını artırmıştır. Keynesyen doktrine uygun pozisyon alan hükümetlerin önemli bir bölümü kamu harcamalarını (özellikle transfer harcamalarını) artırmak zorunda kalmıştır. İlgili dönemde hemen her ülkede kamu harcamalarında önemli artışlar olurken ekonomik daralmalara bağlı olarak vergi gelirlerinde de önemli azalmalar olmuştur. Bu çalışmada da üzerinde ağırlıklı olarak durulan husus; pandemi dönemi vergi gelirleri büyüme arasındaki ilişkidir. Ekonomik daralmanın görüldügü dönemlerde vergi gelirlerinin azalması, genişleme dönemlerinde ise vergi gelirlerinin artması beklenmektedir. Bu durum aynı zamanda vergi yapısının esnekliğini ve konjonktüre ne denli uyumlu olduğunu göstermektedir.

Ekonominin daralma ve genişleme dönemlerine, vergi gelirlerinin verdiği tepki vergi türlerine ve vergi yapısına göre farklılıklar göstermektedir. Ekonomik gelişmelerden doğrudan etkilenen kişisel gelir vergileri esnekliği en yüksek olan vergi türüdür. Gelir veya servetin kullanılmasıyla doğan harcamalar üzerinden alınan vergilerin de dönemsel esnekliği oldukça yüksektir. Temel mal ve hizmetlerin vergi dışı bırakılması ya da çok düşük oranlı vergilendirilmesi halinde harcamalar üzerinden alınan vergilerin dönemsel esnekliğinin daha da arttığı belirtilmektedir. Servet vergilerinin dönemsel esnekliği ise; ekonomik yapıya göre farklılık gösterebilmektedir. (Turhan, 2020, s.319-324). Servetin büyük bir kısmının kayıt dışı olduğu (paha biçilememe, değerleme sorunları vb. dahil) ve/veya servetin yeterince vergilendirilemediği ekonomilerde, servet vergilerinin dönemsel esnekliği pek fazla anlam ifade etmeyecektir. Bu açıdan ekonomik daralma dönemlerinde vergi politikaları gelir ve harcamalar üzerinden alınan vergiler ile daha kolay yürütülebilir. Ekonomik kriz dönemlerinde alınacak servet vergileri ile transfer harcamalarının finanse edilmesi de düşünülebilir. 
Ülkelerin vergi yapıları ve vergi gelirleri kalkınma seviyesiyle orantılıdır. Ülkeler gelişip kalkındıkça, vergi yapısı güçlenmekte ve vergilerin kamu harcamalarını karşılama oranı artmaktadır. Aynı zamanda modern devletlerin gelir kalemlerine bakıldığında büyük bir kısmının vergi gelirlerinden oluştuğu görülmekte ve bu durum bir gelişmişlik göstergesi olarak sayılmaktadır. Bir ekonomide toplam gelir arttıkça vergilendirilebilir kapasitede gelire orantılı olarak artmaktadir.

Az gelişmiş ve gelişmekte olan ülkelere yönelik yapılan bir çalışmada kişi başına gayrisafi milli hasıla (GSMH) artışının, toplam vergi gelirlerinin GSYİH'ya oranları arasında bir ilişki olup olmadığı araştırılmıştır. Çalışma sonucunda; kişi başına gayrisafi milli hasıla ile toplam vergi geliri/GSYİH arasında güçlü ve pozitif yönde bir ilişki bulunmuştur. Dolayısıyla kişi başına GSMH'nin artışı toplam vergi geliri/GSYİH'yı da de artırmaktadır (Akkaya, 1998, s.261).

G7 (Fransa, Almanya, İtalya, İngiltere, Kanada, Japonya, ABD) ve BRIC-T (Brezilya, Rusya, Hindistan, Çin, Türkiye) ülkelerinde vergi gelirlerinin belirleyicileri üzerine yakın dönemde panel veri analiz yöntemiyle yapılan bir çalışmada; her iki ülke grubunda da kişi başına düşen milli gelir arttıkça vergi gelirlerinin yükseldiği snucuna ulaşılmıştır. Hatta her iki ülke grubunda vergi gelirlerini etkileyen en önemli değişkenin kişi başına düşen gelir olduğu ifade edilmiştir. Yine sanayi üretim endeksinde ortaya çıkan artışın vergi gelirlerini artıracağı, sanayi üretim endeksinin \%1 artışı, G7 ülkelerinde vergi gelirlerini \%0.02 oranında, BRIC-T ülkelerinde ise \%0.64 oranında arttırdığı sonucuna ulaşılmıştır (Kutbay, 2019, s.611). Ülkelerin milli gelir artışının vergileme kapasitesini ve dolaylı olarak vergi gelirlerini artıracağını ifade edebiliriz. Bu açıdan çalışmamızda, 2020 yılına ilişkin GSYİH yerine bağımlı değişken olarak aylık sanayi üretim endeksi verileri alınmış ve çeşitli sonuçlara ulaşılmıştır.

GSYİH'nun arttığı bir ülkede kişi başına düşen gelirlerde yükselmektedir. Literatür incelendiğinde birçok ampirik çalışma ile de kişi başına gelir ve/veya GSYİH'nın artışı ile vergi gelirlerinin artışı arasında anlamlı bir ilişki olduğu sonucu ortaya çıkmıştır.

Vergiler, en etkili maliye politikası araçlarından birisidir. Vergi gelirlerinin ekonomik yapıya duyarlı olması, ekonomi yönetimlerine geniş bir hareket alanı sağlamaktadır. Ekonomide yaşanan deflasyonist ve/veya enflasyonist dönemlerde, vergi gelirlerinin otomatik istikrar aracı olarak ön plana çıkması 
beklenmekte ve arzu edilmektedir. Vergi esnekliği ve vergi canlılığ 1 kavramları ile maliye yazınında kendine yer bulan bu durum ekonomik krizlerin daha kolay yönetilmesine olanak sağlamaktadır.

Vergi gelirlerindeki değişimin, gayri safi yurt içi hasıladaki değişime oranlanması halinde vergi esnekliği elde edilmektedir. Vergi esnekliği, vergi gelirlerinin olağan durumda artış veya azalışlarına göre tespit edilmekteyken vergi canlılığı ise daha geniş kapsamlı olup vergi sistemine yapılan müdahaleler neticesinde ortaya çıkan değişimi de ölçmeye yarar (Nalraj, 2015, s.522).

Vergi gelirlerinin esnekliği; vergi gelirlerinde ortaya çıan yüzde değişimin, aynı dönemde GSYİH' da meydana gelen yüzde değişime oranı olarak ifade edilmektedir (Akar; 2013, s.28; Turhan, 2002, s.62). Vergi esnekliği esasında vergi politikasında ve kurallarında herhangi bir değişiklik olmadığı durumda vergi gelirlerinin GSYİH karşısındaki değişiminin ne kadar olduğunu ölçmektedir. Vergi esnekliği genelde hangi vergilerin daha esnek olduğunu, GSYİH'de ortaya çıan artışların hangi vergi gelirlerini daha fazla artırdığının belirlenmesine fayda sağlar (Haughton, 1998, s.3).

30 OECD ülkesine yönelik yapılan ve 1989-2008 yılları verilerini ele alan bir çalışmada; kişi başına gelirde meydana gelen 1 birimlik artışın, vergi gelirlerini 1 birimden daha az oranda artırdığı bu oranın yaklaşık 0,3-0,5 arasında olduğu, gelir artışı ile vergi gelirleri arasında pozitif yönlü ve uzun dönemli bir ilişki bulunduğu, vergi esnekliği katsayısının esnek olmadığı sonucuna ulaşılmıştır (Hepaktan ve Çınar, 2011, s.149-150).

OECD tarafindan yayımlanan 2020 gelir istatistikleri raporu incelendiğinde; 1965-2018 yılları arısında OECD bölgesindeki ortalama vergi/GSYİH oranı \% 24,8'den \% 33,9'a yükselmiştir. 53 yıllık seride vergi/GSYİH oranı yaklaşı \% 9 oranında yükselmiştir. Bu durum kamu gelirlerinin arttı̆̆ını ve/veya kamunun ekonomik yapıdan daha fazla kaynak temin ettiğini göstermektedir. OECD raporunda; ortalama rakamın vergi çeşitliliğini sakladığ1 ifade edilerek bazı ülkeler üzerinden örnekler verilmiştir. Örneğin; vergi/GSYİH ortalaması 1965 yılında Türkiye'de \%10,6 (en düşük) iken Fransa' da \%33,7 (en yüksek) olarak tespit edilmiştir. 2018 yılında ise bu oranlar Meksika'da \%16,2 (en düşük) Fransa'da \%45,9 olarak gerçekleşmiştir. Bu oran Türkiye'de 2018 yllında \%24 olmuştur. Neredeyse tüm OECD ülkelerinde yüksek vergilere doğru bir eğilim olduğu ve kamu sektöründe yaşanan yüksek miktarlı harcama artışını finanse etme ihtiyacının olduğu belirtilmiştir (OECD, 2020). 
Vergi canlılığı, genellikle vergi esnekliği kavramıyla birlikte anılmakta ve karışıklıklara neden olmaktadır. Bu karışıklığın nedeni vergi canlılığı kavramının vergi esnekliğini kapsamasıdır. Mevcut vergi politikası ve uygulamalarıyla vergi gelirindeki değişimin, GSYİH'deki değişime oranlanması vergi esnekliğini ifade ederken, vergi sistemine devlet tarafından müdahale edilmesi sonucu vergi gelirlerinde ortaya çıan toplam değişimin GSYİH'deki değişime oranlanması da vergi canlılı̆̆ denilmektedir (Haughton, 1998, s.1; Ertürk Atabey vd., 2009, s.112).

Vergi canlılı̆g 1 1'den büyük ise GSYİH'deki artıştan daha fazla oranda vergi geliri elde edilmesi söz konusudur ve vergi otomatik stabilizatör olarak görevini yerine getirmiştir. Vergi canlılığını 1'e eşit olması durumunda vergi GSYIH ile hareket ederken bu rakamın 1'den küçük olması verginin otomatik istikrarlandırıc olarak daha az işleve sahip olduğu anlamına gelir. 2003 yılından itibaren 2009 yılında yaşanan krize kadar geçen süreçte, OECD ülkelerinin nominal vergi gelirleri artışı, nominal GSYİH'den daha fazla oranda gerçekleşmiştir. Ancak 2009 yllında bu oran tam tersi olarak gerçekleşmiş ve vergi gelirleri GSYİH' den daha fazla oranda azalmıştır. OECD ortalamalarına bakıldığında bu durum vergi canlılığının 1'den büyük olduğunu göstermektedir (Belinga vd., 2014, s.4).

OECD ülkeleri için 1965-2012 yıllara arasında vergi canlılığını analiz eden bir çalışmada; uzun dönemde vergi canlılığının birçok ülkede 1'i aştığı sonucu elde edilmiştir. Bu durumda GSYİH büyümesi bütçenin gelir tarafı aracılığıyla mali performansın iyileştirilmesine yardımcı olmuştur. Bu çalışmada vergi canlılığının 1980 yılından bu yana azaldığı ancak son dönemde yine artmaya başladığı sonuçlarına da ulaşılmıştır (Belinga vd., 2014, s.16). Daha öncede vergi esnekliğinde belirtildiği üzere; ülkeler vergi esnekliklerinin ve vergi canlılıklarının 1'den yüksek olmasını arzu ederler. Daralma dönemlerinde ekonomik krizin derinleşmesini ve/veya vergilerin daha fazla daraltıcı olmasını engellemek açısından esnekliğin birden büyük olması önemlidir. Tabii olarak genişleme dönemlerinde de enflasyonist etkiye sebep olunmaması için vergi gelirlerinin otomatik artması istenmektedir. Bunlara ilaveten literatürde pek fazla yer verilmediği görülen, siyasi iktidarların vergi politikalarının etkinliğinden yararlanabilme ve politikaların karşılıksız olmaması açısından da vergi canlılı̆̆ 1 çok önemli bir yer tutmaktadır. Örneğin; bir kısım mal ve hizmet grubu üzerinde vergi oranlarının düşürülmesi vergi gelirlerini 
ya da talebi artırmıyor ise orada vergi canlılığının etkinliğinden söz edilemeyecektir.

Geçmişten günümüze yaşanan iktisadi ekonomik ve doğal/yapışıl şoklar nedeniyle çeşitli ekonomik krizler ortaya çımıştır. Yakın tarihte birinci ve ikinci dünya savaşları, 1929 yılında başlayan küresel iktisadi kriz ve 1970'li yıllarda stagflasyonla birlikte yaşanan petrol şokları, 2008 yılında ABD'de ortaya çıkan mortgage krizi bunların en önemlileri olarak sayılabilir. Geçmiş krizlerde küreselleşmenin etkisinin düşük olması nedeniyle tüm ülkeler krizden ayn oranda etkilenmemiştir. Ancak 1990'lı yıllardan itibaren internet ve elektronik ortamdaki gelişmeler dünyayı tek bir düzlemde birleştirmiş ve küreselleşme en yüksek seviyeye ulaşmıştır. Bu nedenle özellikle 2008 yılında ortaya çıan kriz tüm dünyayı derinden etkilemiştir. Bu krizlerin ise vergi gelirlerine farklı etkileri olmuştur. Örneğin; Peacock-Wiseman sıçrama teziyle de ortaya konulduğu üzere savaşlar kamu harcamalarını dolayısıyla vergi gelirlerini artırıcı etki göstermişlerdir. Diğer yandan 1980'ler sonrası özelleştirme politikalarının etkisiyle kamu harcamalarının azaltıldığı ifade edilse de artış trendi halen devam etmektedir. 2008 yılında dünya genelinde yaşanan ekonomik kriz ile GSYİH’ler oldukça sert düşüş göstermiş ancak vergi gelirleri buna paralel bir düşüş göstermemişlerdir. Bu çalışmayla GSYİH'lerin keskin bir şekilde düşüşüne neden olan salgın hastalığın vergi gelirlerine olan etkisi araştırılmıştır.

Literatür açısından çalışma sonucundan beklenen Covid-19 salgın hastalığı nedeniyle ülkelerin GSYİH'lerindeki düşüşe paralel olarak vergi gelirlerinin de düşmesidir. Ayrıca salgın hastalık döneminde boyutları farklı olmakla birlikte tüm ülkeler çeşitli mali teşvik, destek, indirim ve istisna açılamıştır. Diğer bir deyişle hükümetlerin vergi gelirlerine müdahalesi söz konusudur. Hükümetlerin vergi uygulamalarında gerçekleştirdiği değişiklikler nedeniyle vergi canlılığının etkilerinin de sonuçlara yansıması beklenmektedir. Ancak bu yansıma olumlu ve vergi gelirlerinin artışı anlamında değil vergi gelirlerinin azalması şeklinde beklenmektedir.

\section{Model, Veri Seti ve Yöntem}

Literatürde vergi gelirlerinin ekonomik büyüme, enflasyon oranları ve faiz oranlarının bir fonksiyonu olarak ifade edildiği teorik ve ampirik çok sayıda çalışmaya rastlamak mümkündür Temiz (2008), Gül ve Kenar (2009), Ekici 
(2009), Göçer ve diğerleri (2010), Mishra (2011), Dackehag ve Hansson (2012), Taha, Loganathan ve Colombage (2012), Muibi ve Sinbo (2013), Velaj ve Prendi (2014), Demir ve Sever (2017), Moździerz (2017), Akbulut (2017), Kutbay (2019).

Regresyon analizinde en kullanışlı araçlardan biri, kukla veya ikili değişkendir. Bir kukla değişken, bir gruptaki bir etkinin veya üyeliğin varlı̆̆ını göstermek amacıyla bazı gözlemler için bir değerini ve geri kalan gözlemler için sıfır değerini alır Greene (2012, s.189). Regresyon modellerinde kukla değişken uygulamaları için bakınız. Laeven ve Valencia (2013); Chang, Rogers ve Zhou (2020); Elgin, Basbug ve Yalaman (2020). Bu çalışmada vergi gelirlerini açıklamada yukarıda sözü edilen makro değişkenlere ilave olarak, kukla değişken (kukla_covid; 2020.M03 - 2021.M01 için 1, diğerleri için 0 olacak şekilde) Covid-19 pandemisinden kaynaklanan ekonomik kriz döneminin etkisini dikkate almak için modele dahil edilmiştir. Verilen bilgiler ışığında çalışmada kurgulanan ekonometrik model (1) no.lu denklemde verilmektedir:

$\operatorname{lnvg}_{t}=\beta_{0}+\beta_{1} \operatorname{lneb}_{t}+\beta_{2} \operatorname{lnenf}_{t}+\beta_{3} \operatorname{lnfo} o_{t}+\delta k u k l a_{-}$covid $+\varepsilon_{t}$

Bu denklemde vergi gelirleri değişkeni (vg) Türkiye Cumhuriyeti Hazine ve Maliye Bakanlığı web sitesi bütçe gerçekleşmeleri merkezi yönetim bütçe gelirlerinin vergi gelirleri (milyon $\mathrm{tl}$ ) değerleri, (eb) ekonomik büyüme değişkenini temsilen sanayi üretim endeksi genel $(2015=100)$ olarak ve (enf) enflasyon oranını temsilen tüketici fiyat endeksi değişkeni genel (2003=100) olarak Türkiye İstatistik Kurumunun İstatistik Veri Portalı'ndan ve faiz oranları değişkeni (fo) Türkiye Cumhuriyeti Merkez Bankası Elektronik Veri Dağıtım Sisteminden 1 Yll ve Daha Uzun Vadeli (TL Üzerinden Açlan MevduatlarAkım \%) olarak temin edilmiştir. $\boldsymbol{\beta}_{\mathbf{0}}$ sabit ve $\boldsymbol{\varepsilon}_{\boldsymbol{t}}$ hata terimi göstermektedir. Modele dahil edilen değişkenlerin katsayılarının beklenen işaretleri aşağıdaki gibidir:

$\boldsymbol{\beta}_{1}, \boldsymbol{\beta}_{2}>\mathbf{0}, \boldsymbol{\beta}_{\mathbf{3}}<\mathbf{0}, \boldsymbol{\delta}<\mathbf{0}$.

Çalışmada; ekonomik büyüme, enflasyon ve faiz oranlarının vergi gelirlerine etkisi Türkiye örneğinde 2006.M01-2021.M01 aralığı aylık verileri kullanılarak incelenmektedir. Tüm seriler mevsimsellik etkilerinden arındırılıp logaritmaları alınarak analizlere dahil edilmişlerdir. 


$$
\begin{aligned}
& =\alpha_{0}+\sum_{i=0}^{p_{1}} \alpha_{1, i} \Delta \operatorname{lnvg}_{t-i}+\sum_{i=0}^{p_{2}} \alpha_{2, i} \Delta \operatorname{lneb} b_{t-i}+\sum_{i=0}^{p_{3}} \alpha_{3, i} \Delta \operatorname{lnenf} f_{t-i} \\
& +\sum_{i=0}^{p_{4}} \alpha_{4, i} \Delta \operatorname{lnfo}_{t-i}+\beta_{1} \operatorname{lneb}_{t-1}+\beta_{2} \operatorname{lnenf}_{t-1}+\beta_{3} \operatorname{lnfo}_{t-1} \\
& +\beta_{4} k u k l a_{-} \text {covid } \\
& +\varepsilon_{t}
\end{aligned}
$$

(2) no.lu eşitlik, çalışmada kullanılan kukla değişkenin de dahil edildiği ekonomik büyüme, enflasyon oranı ve faiz oranları açıklayıcı değişkenlerinin vergi gelirleri üzerindeki etkilerini kısa ve uzun dönem için yansıtan standart ARDL $\left(\boldsymbol{p}_{1}, \boldsymbol{p}_{2}, \boldsymbol{p}_{3}, \boldsymbol{p}_{\mathbf{4}}\right)$ modelini göstermektedir.

(2) no.lu eşitlikte yer alan model, kukla değişkenin de dahil olduğu açıklayıcı değişkenlerin vergi gelirleri üzerine simetrik etkilerini incelemektedir. Standart yaklaşımın yanında açıklayıcı değişkenlerin muhtemel asimetrik etkilerinin vergi gelirlerine etkilerini incelemek amaciyla Shin ve diğerleri (2014) tarafından geliştirilen doğrusal olmayan ARDL (NARDL) metodolojisi de kullanılmıştır. Bu amaçla vergi gelirlerinin ekonomik büyüme değişkeninde meydana gelecek bir artış veya bir azalışa aynı büyüklükte yani simetrik olmayan bir tepki verebileceğinden hareketle oluşturulan NARDL modelini kurgulamak için öncelikle ekonomik büyüme değişkeninin bileşenlerine ayrıştırılması gerekmektedir.

$\boldsymbol{e b}_{\boldsymbol{t}}^{+}$: birikimli pozitif şokları,

$\boldsymbol{e} \boldsymbol{b}_{\boldsymbol{t}}^{-}$: birikimli negatif şokları,

göstermekte olduğu varsayımı ile aşağıdaki şekilde formüle edilebilir:

$$
e^{+} b_{t}^{+}=\sum_{i=1}^{t} \quad \Delta e b_{i}^{+}=\sum_{i=1}^{t} \quad \max \left(\Delta e b_{i}, 0\right)
$$

$$
e b_{t}^{-}=\sum_{i=1}^{t} \quad \Delta e b_{i}^{-}=\sum_{i=1}^{t} \quad \min \left(\Delta e b_{i}, 0\right)
$$

(2) no.lu denklemde formüle edilen doğrusal ARDL modeline (3) ve (4) no.lu ekonomik büyüme değişkeninin birikimli bileşenlerinin eklenmesi ile doğrusal olmayan ARDL -NARDL $\left(\boldsymbol{p}_{1}, \boldsymbol{p}_{2}, \boldsymbol{p}_{3}, \boldsymbol{p}_{4}, \boldsymbol{p}_{5}\right)$ denklemi elde edilmekte ve aşağıda (5) no.lu denklemde verilmektedir: 


$$
\begin{aligned}
& \Delta \operatorname{lnvg}_{t}=\alpha_{0}+\sum_{i=0}^{p_{1}} \alpha_{1, i} \Delta \ln v g_{t-i}+\sum_{i=0}^{p_{2}} \alpha_{2, i} \Delta \ln e b_{t-i}^{+} \\
& +\sum_{i=0}^{p_{3}} \alpha_{3, i} \Delta \operatorname{lne} b_{t-i}^{-}+\sum_{i=0}^{p_{4}} \alpha_{4, i} \Delta \operatorname{lnenf} f_{t-i} \\
& +\sum_{i=0}^{p_{5}} \alpha_{5, i} \Delta \ln f o_{t-i}+\beta_{1} \ln e b_{t-1}^{+}+\beta_{2} \operatorname{lne} b_{t-1}^{-} \\
& +\beta_{3} \operatorname{lnenf}_{t-1}+\beta_{4} \operatorname{lnfo} o_{t-1}+\beta_{5} \text { kukla_covid } \\
& +\varepsilon_{t}
\end{aligned}
$$

\section{Ampirik Çalışma Bulguları}

\section{Data}

Tablo 1. Değişkenlere Ait Tanımlayıcı İstatistikler

\begin{tabular}{lllll}
\hline Değişkenler & lnvg & lneb & lnenf & lnfo \\
\hline Ortalama & 10.19097 & 4.465602 & 5.445582 & 2.429444 \\
Medyan & 10.23808 & 4.471722 & 5.409197 & 2.317585 \\
Maksimum & 11.35360 & 4.869475 & 6.238372 & 3.145574 \\
Minimum & 9.215677 & 3.953684 & 4.814272 & 1.856391 \\
Std. Sapma. & 0.565817 & 0.232254 & 0.387807 & 0.299078 \\
Jarque-Bera & 9.947222 & 11.84189 & 9.276372 & 12.88731 \\
Olasılık & 0.006918 & 0.002683 & 0.009675 & 0.001591 \\
Gözlem Sayısı & 181 & 181 & 181 & 181 \\
\hline
\end{tabular}

Tablo 1'de çalışmada ele alınan 2006.M01-2021.M01 dönemine ait 181 adet gözlem değerinden oluşan serilerin tanımlayıcı istatistikleri verilmiştir.

Tablo 2: Değişkenlere Ait Korelasyon Matrisi

\begin{tabular}{lllll}
\hline Değişkenler & Lnvg & lneb & lnenf & lnfo \\
\hline Lnvg & 1.000000 & & & \\
Lneb & 0.950490 & 1.000000 & & \\
Lnenf & 0.984090 & 0.910665 & 1.000000 & \\
Lnfo & -0.183564 & -0.155085 & -0.129686 & 1.000000 \\
\hline
\end{tabular}

Tablo 2'de verilen korelasyon matrisine göre, vergi gelirleri ile modelde açıklayıcı değişken olarak yer alan ekonomik büyüme ve enflasyon değişkenleri arasında pozitif yönlü ve oldukça kuvvetli bir ilişki söz konusu iken faiz oranları ile ise ters yönlü ve zayıf bir ilişki söz konusudur. 


\section{Birim Kök Testleri}

Çalışmanın analiz kısmında kullanılacak olan vergi gelirleri bağımlı değişkeni ile sanayi üretim endeksi, faiz oranları ve tüketici fiyat endeksi bağımsız değişkenlerinin durağanlık sınamaları gerçekleştirilmiştir. Bunun için, Dickey ve Fuller (1979)'un geleneksel Augmented Dickey Fuller (ADF) ile Phillips-Perron (PP) (1988) birim kök testleri kullanılmıştır. Birim kök test sonuçları aşağıda Tablo 3'te verilmiştir.

Tablo 3. Birim Kök Test Sonuçlarn

\begin{tabular}{|c|c|c|c|c|c|c|c|c|}
\hline \multirow{2}{*}{ Değişkenler } & \multicolumn{4}{|l|}{ ADF Testi } & \multicolumn{4}{|c|}{ Philips Perron Testi } \\
\hline & Düzey & Olasılık & Birinci Fark & Olasılık & Düzey & Olasılık & Birinci Fark & Olasılık \\
\hline lnvg & 0.275531 & 0.9764 & -15.94861 & 0.0000 & -0.441017 & 0.8982 & -103.1694 & 0.0001 \\
\hline lneb & -1.271496 & 0.6425 & -22.18732 & 0.0000 & -1.640334 & 0.4599 & -33.44502 & 0.0001 \\
\hline $\operatorname{lnenf}$ & 2.570133 & 1.0000 & -9.834670 & 0.0000 & 3.124299 & 1.0000 & -9.892162 & 0.0000 \\
\hline $\operatorname{lnfo}$ & -2.082462 & 0.2521 & -9.693428 & 0.0000 & -2.040946 & 0.2692 & -9.737918 & 0.0000 \\
\hline
\end{tabular}

Tablo 3'teki değişkenlerin birim kök testi istatistik ve olasılık sonuçları incelendiğinde, \% 5 anlamlılık seviyesinde, değişkenlerin düzeyde durağan olmadıkları görülmektedir. Bununla birlikte ilk farkları alındığında ise değişkenler durağan hale geldiği gelmektedir. Bu anlamda değinilmesi gereken önemli bir hususta çalışmada kullanılan ARDL metodolojisinin uygulanabilmesi için gerekli şart olan değişkenlerden hiçbirinin ikinci seviyede durağan olma I(2) durumunun olmadığı görülmektedir.

\section{Eşbütünleşme}

\section{Doğrusal ARDL}

Tablo 4. Bağımlı Değişken: $\Delta \operatorname{lnvg}_{t}$ ile kurulan ARDL $(7,12,6,11)$ Modelinin Sonuçları

\begin{tabular}{|c|c|c|c|}
\hline \multicolumn{4}{|c|}{ Panel A: Kısa Dönem Katsayılar } \\
\hline Değişken & Katsayı & Standart Hata & Olasılık \\
\hline$\Delta \operatorname{lnvg}_{t-1}$ & -0.362968 & 0.162611 & 0.0273 \\
\hline$\Delta \operatorname{lnvg}_{t-2}$ & -0.340221 & 0.160554 & 0.0360 \\
\hline$\Delta \operatorname{lnvg}_{t-3}$ & -0.129184 & 0.155317 & 0.4071 \\
\hline$\Delta \operatorname{lnvg}_{t-4}$ & -0.009105 & 0.144398 & 0.9498 \\
\hline$\Delta \operatorname{lnvg}_{t-5}$ & 0.111873 & 0.119319 & 0.3502 \\
\hline$\Delta \operatorname{lnvg}_{t-6}$ & 0.191724 & 0.077980 & 0.0153 \\
\hline$\Delta \operatorname{lneb} b_{t}$ & 0.634678 & 0.076414 & 0.0000 \\
\hline$\Delta \operatorname{lne} b_{t-1}$ & 0.276685 & 0.141599 & 0.0529 \\
\hline$\Delta \operatorname{lneb}_{t-2}$ & 0.327607 & 0.149252 & 0.0300 \\
\hline$\Delta \operatorname{lneb}_{t-3}$ & 0.080511 & 0.149854 & 0.5920 \\
\hline
\end{tabular}


Hamza Erdoğdu- Murat Demir- Rıdvan Önder

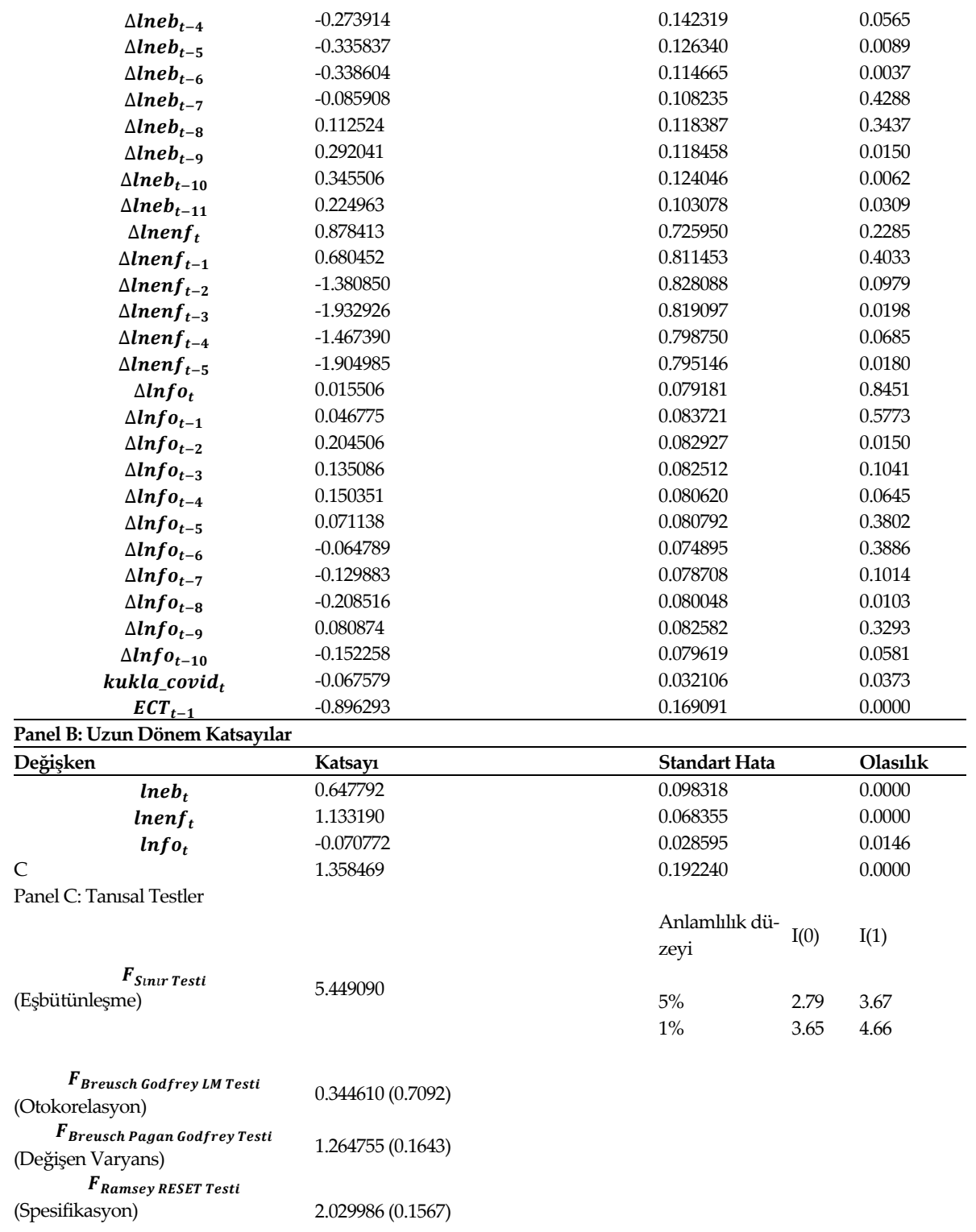


CUSUMSQ

(Stabilite)

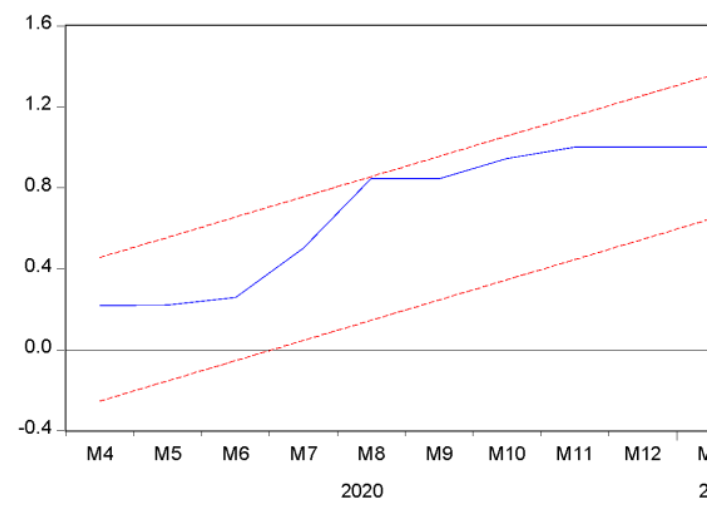

${ }^{*} \Delta$ : Birinci fark işlemcisi; $\boldsymbol{E C T}_{\boldsymbol{t}-\mathbf{1}}$ : Hata Düzeltme Katsayısı.

*Parantez içerisindeki değerler test istatistiklerine ait olasillk değerleridir.

Tablo 4'te doğrusal ARDL $(7,12,6,11)$ model sonuçları yer almaktadır. İlgili tablo üç panelden oluşmaktadır. Panel A, bağımlı değişkenin $\Delta \boldsymbol{l n} \boldsymbol{v} \boldsymbol{g}_{\boldsymbol{t}}$ olarak alındığı modelin kısa dönem katsayılarını Panel B ise, söz konusu modelin uzun dönem katsayılarını göstermektedir. Panel C, değişkenler arasında eşbütünleşmenin var olup olmadığını test eden Sınır testi sonuçlarına ilave olarak regresyon modelinin tahminlerine ilişkin çıkarımlar yapmadan önce karşılanması gereken varsayımları (koşulları) gösteren tanısal test sonuçlarını göstermektedir. Bu tanısal testler; otokorelasyon sorununun araştırılması için Breusch-Godfrey LM(Lagrange Multiplier) testi, değişen varyans sorununun araştırılması için Breusch Pagan Godfrey testi, modelde fonksiyonel formun yanlış tanımlanıp tanımlanmadığını tespit etmek için Ramsey RESET (Regression Specification Error Test) testi ve model parametrelerinin stabilitesinin (kararlı) olup olmadığını belirlemek için CUSUMSQ testidir.

Klasik regresyon modelinin varsayımlarının sağlanıp sağlanmadığını kontrol etmek için öncelikle model sonuçlarına ilişkin Panel C'de verilen tanısal testlerin sonuçlarına bakmak yerinde olacaktır. Bu test sonuçlarına göre modelde otokorelasyon ve değişen varyans problemi bulunmamaktadır. İlave olarak modelin fonksiyonel kalıbı yanlış tanımlanmamış ve model parametrelerinin stabil olduğu görülmektedir. Varsayımların karşılanmasıyla birlikte ele alınan modelin tahminlerine ilişkin ekonometrik çıkarımlar yapmak mümkün olacaktır. 
İlk olarak modeldeki değişkenler arasında bir eşbütünleşme ilişkisinin söz konusu olup olmadığı Panel C'de yer alan Sınır Testi F-istatistiğine bakılarak kararlaştırılabilir. Buna göre, \%1 anlamlılık düzeyinde hesaplanan F test istatistik değeri (5.449), kritik tablo üst değerinden büyüktür. Bundan dolayı değişkenler arasında eşbütünleşme ilişkinin olmadığını ifade eden $\boldsymbol{H}_{\boldsymbol{o}}$ yokluk hipotezini reddetmek mümkün olmaktadır. Yani, çalışmada ele alınan dönem aralığında vergi gelirleri ile ekonomik büyüme, enflasyon ve faiz oranları değişkenleri arasında bir uzun dönem ilişkinin var olduğu görülmektedir. Değişkenler arasında bir uzun dönem ilişkisinin varlığı ile birlikte Panel B'de verilen modelde yer alan açılayıcı değişkenlere ait uzun dönem parametre tahminlerine bakıldığında tümünün iktisadi teoriye uygun işaretlere sahip ve \% 5 anlamlılık seviyesinde istatistiksel anlamlı olduğu görülmektedir. Buna göre, diğer değişkenlerin etkisi sabit tutulduğunda, ekonomik büyüme de meydana gelen \% 1'lik bir artışın vergi gelirlerini yaklaşık olarak \% 0.65 oranında arttırdığı söylenebilir. Diğer bir açıklayıcı değişken olan enflasyon oranında meydana gelebilecek \% 1'lik bir artışın ise vergi gelirlerinde \% 1.13 oranında artışa yol açacağı görülmektedir. Son olarak, faiz oranlarında meydana gelebilecek \% 1'lik bir artışın ise vergi gelirlerini \% 0.07 oranında azalttı̆̆ 1 ifade edilebilir.

Çalışmada, Covid-19 pandemisinden kaynaklanan ekonomik krizin etkisini modele taşımak için tercih edilen kukla değişken (kukla_covid) katsayısı da Panel A'da yer almaktadır. Bu katsayının negatif (-0.067579) ve \%1 anlamlılık seviyesinde istatistiksel anlamlı olduğu görülmektedir. Bu negatif kukla değişken katsayısı, Covid-19 küresel salgın krizinin Türkiye' de vergi gelirlerini olumsuz etkilediğini göstermektedir. Bu katsayının yorumu şu şekildedir: Diğer tüm değişkenlerin etkisi sabit tutulduğunda, kriz kuklasında olumlu bir değişiklik (yani küresel Covid-19 krizinin etkileri bir birim daha şiddetli hale geldiğinde) olduğunda, aylık vergi gelirleri yaklaşık olarak \% 0.07 oranında azalmaktadır.

Panel A'da yer alan son katsayı, değişkenler arasında eşbütünleşmenin tespit edilmesinin ardından hata düzeltme modelinin tahmin edilmesiyle elde edilen hata düzeltme katsayısıdır. Modelde bu katsayının negatif (0.896293 ) ve \%1 anlamlılık seviyesinde istatistiksel anlamlı olduğu görülmektedir. Bu katsayı, vergi gelirlerinin açıklandığı değişkenlerin birlikte oluşturduğu sistemin bir şoka maruz kalması durumunda bir ay (dönem) sonunda söz konusu şokun yüzde 90'nının düzeltilebildiğini ifade etmektedir. 


\section{NARDL - Doğrusal Olmayan ARDL}

Yukarıda doğrusal ARDL modeli kurulurken modelde bulunan ekonomik büyüme, enflasyon oranı ve faiz oranları değişkenlerin tamamının vergi gelirleri üzerindeki etkilerinin hem kısa dönemde hem de uzun dönemde simetrik olduğu varsayımına dayanmaktadır. Bu bölümde ise ekonomik büyüme değişkenindeki pozitif ve negatif değişikliklerin vergi gelirleri üzerindeki etkisinin simetrik olmadığı varsayımı ile Tablo 5'teki sonuçlara ulaşılmiştır.

Tablo 5. Bağımlı Değişken: $\Delta \operatorname{lnvg}_{t}$ ile Kurulan NARDL $(3,3,0,2,0)$ Modelinin Sonuçlar

\begin{tabular}{|c|c|c|c|c|}
\hline \multicolumn{5}{|c|}{ Panel A: Kısa Dönem Katsayılar } \\
\hline Değişken & Katsayı & Standart Hata & & Olasılık \\
\hline$\Delta \operatorname{lnvg}_{t-1}$ & -0.261503 & 0.081138 & & 0.0015 \\
\hline$\Delta \operatorname{lnv} g_{t-2}$ & -0.183806 & 0.062251 & & 0.0036 \\
\hline$\Delta l n e b \_p o s_{t}$ & 0.460585 & 0.093440 & & 0.0000 \\
\hline$\Delta l n e b \_p o s_{t-1}$ & 0.128513 & 0.093565 & & 0.1715 \\
\hline$\Delta$ lneb_pos ${ }_{t-2}$ & 0.334063 & 0.096959 & & 0.0007 \\
\hline$\Delta \operatorname{lnenf}_{t}$ & 1.512327 & 0.591490 & & 0.0115 \\
\hline$\Delta \operatorname{lnenf_{t-1}}$ & 1.544824 & 0.592756 & & 0.0100 \\
\hline kukla_covid & -0.015684 & 0.018912 & & 0.4082 \\
\hline$E C T_{t-1}$ & -0.965865 & 0.101401 & & 0.0000 \\
\hline \multicolumn{5}{|c|}{ Panel B: Uzun Dönem Katsayılar } \\
\hline Değişken & Katsayı & Standart Hata & & Olasılık \\
\hline lneb_pos ${ }_{t}$ & 0.739515 & 0.056557 & & 0.0000 \\
\hline lneb_neg & 0.640877 & 0.074868 & & 0.0000 \\
\hline $\operatorname{lnenf}_{t}$ & 0.737446 & 0.103217 & & 0.0000 \\
\hline $\operatorname{lnfo} o_{t}$ & -0.092908 & 0.017348 & & 0.0000 \\
\hline $\mathrm{C}$ & 5.893500 & 0.494861 & & 0.0000 \\
\hline \multicolumn{5}{|l|}{ Panel C: Tanisal Testler } \\
\hline \multirow{3}{*}{$\begin{array}{l}\boldsymbol{F}_{\text {Sınır Testi }} \\
\text { (Eşbütünleşme) }\end{array}$} & & Anlamlılık düzeyi & $\mathrm{I}(0)$ & $\mathrm{I}(1)$ \\
\hline & 14.67156 & $5 \%$ & 2.56 & 3.49 \\
\hline & & $1 \%$ & 3.29 & 4.37 \\
\hline $\begin{array}{l}\quad \boldsymbol{F}_{\text {Breusch Godfrey LM Testi }} \\
\text { (Otokorelasyon) }\end{array}$ & $1.625951(0.1999)$ & & & \\
\hline $\begin{array}{l}\boldsymbol{F}_{\text {Breusch Pagan Godfrey Testi }} \\
\text { (Değişen Varyans) }\end{array}$ & $1.526164(0.1128)$ & & & \\
\hline $\begin{array}{l}\boldsymbol{F}_{\text {Ramsey }} \text { RESET Testi } \\
\text { (Spesifikasyon) }\end{array}$ & $0.698599(0.4045)$ & & & \\
\hline
\end{tabular}




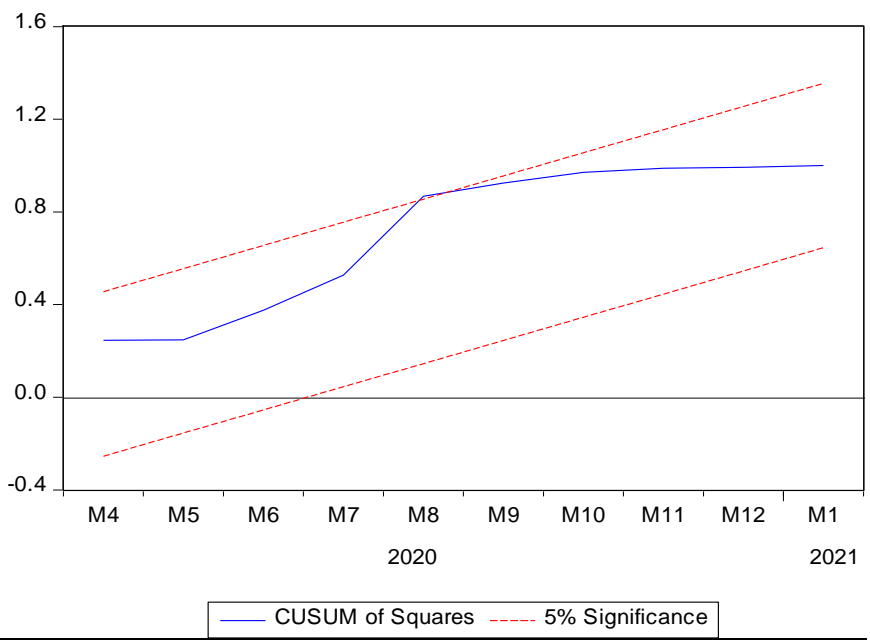

Tablo 5'te doğrusal olmayan ARDL $(3,3,0,2,0)$ model sonuçları yer almaktadır. İlgili tablo Tablo 4 'te olduğu gibi üç panelden oluşmaktadır. Panel C'de verilen tanısal testlerin sonuçlarına bakıldığında bu modelde de otokorelasyon ve değişen varyans probleminin bulunmadığı görülmektedir. Benzer şekilde modelin fonksiyonel kalıbının yanlış tanımlanmadığ 1 ve model parametrelerinin stabil olduğu görülmektedir. Modeldeki değişkenler arasında bir eşbütünleşme ilişkisinin varlığı için Panel C'de yer alan Sınır Testi F-istatistik değeri (14.67156) kontrol edildiğinde, \%1 anlamlılık düzeyinde kritik tablo üst değerinden (4.37) oldukça büyük olduğu görülmektedir. Dolay1sıyla değişkenler arasında eşbütünleşme ilişkinin olmadığının ifade edildiği $\boldsymbol{H}_{\boldsymbol{o}}$ yokluk hipotezini reddetmek için yeterince kant olduğu görülmektedir. Diğer bir ifadeyle, ele alınan dönemde bağımlı değişken vergi gelirleri ile bu değişkeni açıklayan diğer değişkenler arasında bir uzun dönem ilişkinin varlığı söz konudur. Panel B' de modelde yer alan açıklayıcı değişkenlerin katsayılarına bakıldığında tümünün iktisadi teoriye uygun işaretlere sahip ve $\% 5$ anlamlılık düzeyinde istatistiksel olarak anlamlı oldukları görülmektedir. Buna göre, diğer değişkenlerin etkisi sabit tutulduğunda, ekonomik büyüme de meydana gelen $\%$ 1'lik pozitif bir şokun vergi gelirlerini yaklaşık olarak \% 0.74 oranında arttırırken, \% 1'lik negatif bir şokun vergi gelirlerini yaklaşık olarak \% 0.64 oranında arttırdığı görülmektedir. İlave olarak, enflasyon oranında meydana gelebilecek \% 1'lik bir artışın ise vergi gelirlerinde yaklaşık \% 
0.74 oranında artışa yol açacağı gözlemlenmektedir. Son olarak, faiz oranlarında meydana gelebilecek \% 1'lik bir artışın ise vergi gelirlerini \% 0.09 oranında azalttığı ifade edilebilmektedir.

Panel A'da yer alan kukla değişken (kukla_covid) katsayının iktisadi beklentiye uygun şekilde negatif (-0.015684) işaretli fakat \% 5 anlamlılık düzeyinde istatistiksel olarak anlamlı olmadığı görülmektedir. Son olarak, değişkenler arasında eşbütünleşmenin tespit edilmesinin ardından hata düzeltme katsayısının iktisadi teoriye uygun şekilde 0 ile -1 aralığında, negatif (0.965865) olduğu ve \%1 anlamlılık seviyesinde istatistiksel anlamlı olduğu görülmektedir. Söz konusu katsayı, vergi gelirlerinin açıklandığı değişkenlerin birlikte oluşturduğu sistemin bir şoka maruz kalması durumunda bir dönem (ay) sonunda söz konusu şokun yaklaşık yüzde 97'sinin düzeltilebildiğini ifade etmektedir.

\section{Varyans Ayrıştırma ve Etki-Tepki Fonksiyonu}

Vergi gelirleri ile açıklayıcı değişkenler arasında bir uzun dönem ilişkinin varlığının gösterilmesinin ardından tahmin edilen vektör hata düzeltme modeli yardımıyla, şokların modelde yer alan değişkenler üzerindeki etkilerinin belirlenmesi amaciyla etki-tepki (impulse-response) fonksiyonları ile varyans ayrıştırması (variance decomposition) yöntemleri kullanılmıştır. Türkiye'nin vergi gelirleri değişkenine ait 24 periyot (aylık) için varyans ayrıştırma sonuçları Tablo 6'da verilmiştir. Bunun yanında modelde ele yer alan her bir değişken bir standart sapmalık şoka maruz kaldığında diğer değişkenlerin buna tepkisini gösteren etki-tepki grafiklerinin gösterimi aşağıda Şekil 1'de verilmiştir.

Tablo 6. Varyans Ayruştırma Sonuçlar

\begin{tabular}{lllll}
\hline Periyot & \multicolumn{1}{c}{ lnvg } & lneb & lnenf & lnfo \\
\hline 1 & 100.0000 & 0.000000 & 0.000000 & 0.000000 \\
2 & 90.03638 & 5.306107 & 3.527813 & 1.129702 \\
3 & 89.20032 & 6.428964 & 3.108376 & 1.262340 \\
4 & 87.67512 & 6.791209 & 3.449237 & 2.084430 \\
5 & 85.32130 & 8.527634 & 3.313505 & 2.837560 \\
6 & 83.44396 & 10.01593 & 3.149639 & 3.390473 \\
7 & 81.56485 & 11.05587 & 3.018855 & 4.360424 \\
8 & 79.56955 & 12.13495 & 2.927525 & 5.367970 \\
9 & 77.76228 & 13.06708 & 2.855423 & 6.315223 \\
10 & 75.98479 & 13.93400 & 2.782830 & 7.298378 \\
11 & 74.26050 & 14.74178 & 2.736167 & 8.261555
\end{tabular}




\begin{tabular}{lllll}
12 & 72.64285 & 15.47359 & 2.703008 & 9.180548 \\
13 & 71.09758 & 16.15456 & 2.673143 & 10.07471 \\
14 & 69.62688 & 16.79567 & 2.649220 & 10.92822 \\
15 & 68.23849 & 17.39279 & 2.630015 & 11.73871 \\
16 & 66.91972 & 17.95628 & 2.613192 & 12.51082 \\
17 & 65.66718 & 18.48983 & 2.598084 & 13.24491 \\
18 & 64.47892 & 18.99417 & 2.584291 & 13.94262 \\
19 & 63.34896 & 19.47284 & 2.571590 & 14.60661 \\
20 & 62.27330 & 19.92841 & 2.559657 & 15.23863 \\
21 & 61.24866 & 20.36214 & 2.548315 & 15.84089 \\
22 & 60.27127 & 20.77573 & 2.537555 & 16.41545 \\
23 & 59.33792 & 21.17071 & 2.527303 & 16.96407 \\
24 & 58.44577 & 21.54827 & 2.517480 & 17.48848 \\
\hline
\end{tabular}

Tablo 6'ya göre ilk periyotta, vergi gelirlerindeki varyasyonun tamam1 vergi gelirleri değişkeni tarafından karşılanmaktadır. Sonraki periyotlarda vergi gelirleri değişkeninin payı düşerken diğer değişkenlerin payları ise artmaktadır. İkinci periyottan itibaren açıklayıcı değişkenler arasında vergi gelirlerinin varyasyonunu açılamada büyüklük sırasıyla ekonomik büyüme, faiz oranı ve enflasyon değişkenlerinin geldiği görülmektedir. İkinci periyotta vergi gelirlerindeki varyasyonun yüzde 90'nı vergi gelirleri değişkeni tarafından karşılanırken, yüzde 10'nu da modeldeki diğer açıklayıcı değişkenlerin katkılarıyla olmaktadır. Bu değişkenlerden ekonomik büyüme yüzde 5.3, enflasyon yüzde 3.5 ve faiz oranları yüzde 1.2 katkı paylarına sahiptirler. Yedinci periyotta vergi gelirlerindeki varyasyonun yüzde 81.5'i vergi gelirleri değişkeni tarafından karşılanırken, geri kalan yüzde $18.5^{\prime}$ luk katkıyı da yüzde 11 oranıla ekonomik büyüme, yüzde 4.3 oranıla faiz oranları ve yüzde 3 oranıyla enflasyon değişkeni vermektedir. Bu periyot için enflasyon değişkeninin vergi gelirlerindeki varyasyonu açıklamada kendi içinde en yüksek katkıyı sunduğu ve sonraki periyotlarda katkısının azaldığı vurgulanması gerekmektedir. Yirmi dördüncü periyotta vergi gelirlerindeki varyasyonun kendisi tarafından açılanma oranı yüzde 58.4'e kadar düşerken, geri kalan yüzde $41.6^{\prime} l 1 k$ katkı da yüzde 21.5 oranyla ekonomik büyüme, yüzde 17.5 oranıla faiz oranları ve yüzde 2.5 oranıla enflasyon değişkeni tarafından sağlanmaktadır. Bir bütün olarak sonuçlar yorumlanmak istenirse, ekonomik büyüme değişkeninin vergi gelirlerindeki değişkenliği diğer değişkenlerle karşılaştırıldığında daha yüksek oranda açıkladığı görülmektedir. Bu sonuç yukarıda verilen NARDL model kurgusunu da destekler nitelik göstermektedir. 
Response to Cholesky One S.D. (d.f. adjusted) Innovations
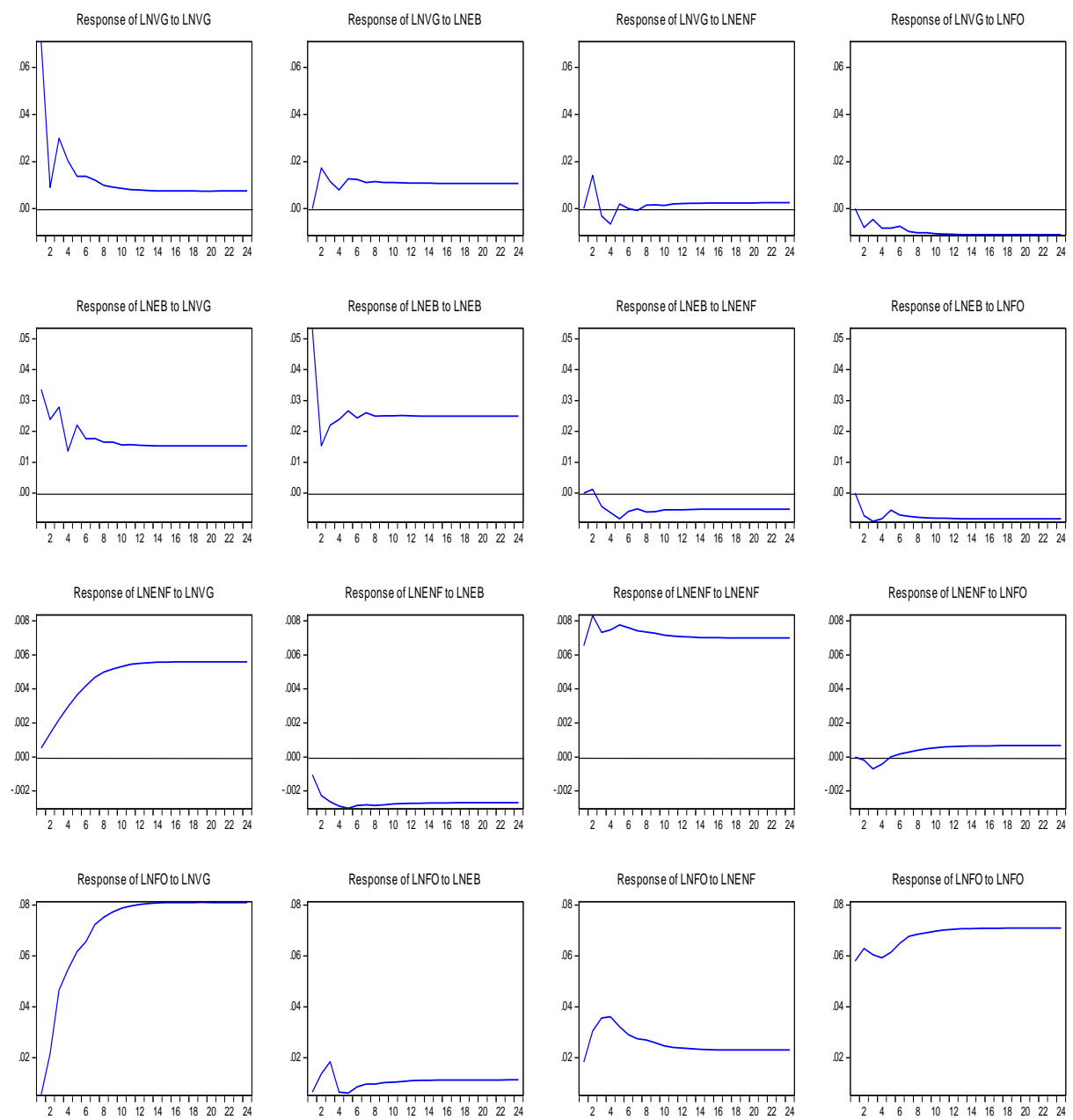

\section{Şekil 1. Bir Standart Sapmalık Şoka Karşılık Değişkenlerin Tepkileri}

Şekil 1'de yer alan bir standart sapmalık şoka karşılık değişkenlerin tepkilerini gösteren grafiklerin; $\boldsymbol{x}$-eksenleri 24 periyotluk (ay) süreyi, $\boldsymbol{y}$-eksenleri ise tepkinin derecesini göstermektedir. Vergi gelirleri değişkeninin kendi şoklarına maruz kaldığında genel olarak pozitif yönde tepki verdiği görülmektedir. Bu tepkilerin; başlangıçtan ikinci aya kadar hızla düşüş gösterdiği, sonrasında üçüncü aya kadar bir miktar arttığı sonrasında ise on ikinci aya 
kadar azalarak geldiği ve son olarak on ikinci aydan olsa yirmi dördüncü aya kadar ise değişmeden sabit kaldığı görülmektedir. Vergi gelirleri değişkeninin ekonomik büyüme değişkenindeki bir birimlik şoka karşı verdiği tepki sıfırdan başlayarak ikinci aya kadar artış göstermekte sonrasında dördüncü aya kadar kısmen azalmakta ve sonrasında sabit bir seyir izlemektedir. Enflasyon değişkeni bir standart sapmalık şoka maruz kaldığında vergi gelirleri değişkeninin sıfırdan başlayarak ikinci aya kadar arttığı, üçüncü haftaya kadar tekrar sıfır seviyesine inmesinin ardından dördüncü ve beşinci aylarda negatif tepki verdiği ve sonrasında sıfır seviyesinde yirmi dördüncü aya kadar devam ettiği izlenmektedir. Son olarak, faiz oranları değişkeni bir standart sapmalık şoka uğradığında vergi gelirlerinin tepkisinin negatif yönlü sekizinci aya kadar dalgalanmakta olduğu ve bu aydan sonra yirmi dördüncü aya kadar aynı düzeyde kaldı̆̆ı şeklindedir.

\section{Sonuç ve Değerlendirme}

Bu çalışmada, Türkiye'de vergi gelirleri ile ekonomik büyüme, enflasyon ve faiz oranları arasındaki ilişki Covid-19 küresel pandeminin muhtemel ekonomik etkileri dikkate alınarak aylık veriler kullanılarak incelenmiştir. Çalışmada ilk olarak değişkenler arasındaki korelasyon matrisi elde edilmiştir. Buna göre, vergi gelirleri ile ekonomik büyüme ve enflasyon değişkenleri arasında pozitif yönlü, faiz oranları ile ise ters yönlü bir ilişkinin olduğunu göstermektedir. Sonrasında, değişkenlerin birim kök sınamalarına bakılmış ve durağanlık düzeyleri tespit edilmiştir. Buna göre çalışmada yer alan değişkenler düzey seviyelerinde durağan değilken birinci farkları alındıklarında durağan hale gelmektedir.

ARDL metodolojisi için gerekli şartların sağlandığının görülmesi üzerine uygulanan Sınır testi sonuçları, incelenen dönem için Türkiye' de vergi gelirleri ile ekonomik büyüme, enflasyon ve faiz oranları arasında bir eşbütünleşme ilişkisinin olduğunu göstermektedir. Uzun dönemde ekonomik büyümede meydana gelecek \% 1'lik bir artışın vergi gelirlerini yaklaşık olarak \% 0.65 oranında arttırdığı, yine enflasyon oranında meydana gelebilecek \% 1'lik bir artışın ise vergi gelirlerinde \% 1.13 oranında artışa yol açacağı tespit edilmiştir. Bununla birlikte, faiz oranlarında meydana gelebilecek \% 1'lik bir artışın ise vergi gelirlerini \% 0.07 oranında azalttığ 
Covid-19 pandemisinden kaynaklanan ekonomik krizin etkisini modele taşımak için tercih edilen kukla değişken katsayısının, negatif (-0.067579) ve \%1 anlamlılık seviyesinde istatistiksel anlamlı olduğu görülmüştür. Bu negatif kukla değişken katsayısı, küresel Covid-19 krizinin etkileri bir birim daha şiddetli hale geldiğinde, aylık vergi gelirlerinin yaklaşık olarak \% 0.07 oranında azalacağını göstermektedir. Çalışmadan elde edilen sonuçlar birlikte değerlendirildiğinde şu hususları vurgulamakta yarar vardır:

Makalenin yazıldığı tarih itibariyle küresel düzeyde ve Türkiye'de üçüncü ve dördüncü dalgalar şeklinde Covid-19 pandemisinin etkisinin sürmesi çeşitli sosyal ve ekonomik kısıtlamaları zorunlu kılmaktadır. Bu durum ülkelerin ekonomik büyümelerinin düşük oranlarda gerçekleşmesi dolaylsıyla vergi gelirlerinin de azalması anlamına gelmektedir. Covid-19 pandemisinin etkisinin bu şekilde artarak sürmesi tasarlanacak regresyon modellerinde söz konusu etkiyi üzerinde taşıması amacıyla yer alacak kukla değişkenlerin istatistiksel olarak anlamlı çımaları ve katsayılarının (etki düzeylerinin) artmasını da beraberinde getirecektir.

Türkiye gibi, genç ve artan bir nüfusa sahip ve her alanda yaşam standartlarını gelişmiş ülkeler seviyesine çıkartmak isteyen, gelişmekte olan bir ülke için sürdürülebilir pozitif büyümenin taşıdığı önemin yadsınamaz oluşudur. Uzun yıllar sürecek bu durumun etkisi devletin kamu finansman ihtiyaçlarının karşılanmasında, borçlanma ve vergi dışı diğer alternatiflere yönelimini minimum düzeyde tutarak yaşanabilecek olası her türlü iktisadi şoklara karşı kamu maliyesi ve hazinesinin elini güçlendirecektir.

Covid-19 salgını süresince çeşitli ekonomilerdeki enflasyon görünümüne bakıldığında; hükümetlerin devasa boyutlu mali teşviklerine rağmen birçok gelişmiş ekonomide enflasyon negatif seyretmektedir. Uluslararası Para Fonu verilerine göre; 2020 yılında Dünya'da enflasyon ortalaması \%2,8'lerde seyretmektedir. Enflasyon verileri, vergi gelirleri için oldukça büyük önem arz etmektedir. Enflasyonun vergi gelirlerini aşındırıcı etkisi(tanzi etkisi) sıklıkla tartışılmasına rağmen, aynı zamanda enflasyon nominal gelirleri artırarak vergi yükünün artışına neden olabilmektedir. Kamu maliyesinde enflasyon ile vergi ilişkisine yönelik olarak ilk akla gelen, talebin baskılanması açsından vergilerin deflasyonist olduğu ve enflasyonist dönemlerde vergi artı̧ı veya vergilerin kamu harcamalarından daha fazla artırılması suretiyle enflasyonun kontrol altına alınabileceğidir (Uluatam, 1990, s.19). Enflasyonist dö- 
nemlerde vergilerin artırılmasının talep üzerinde baskı yaratması beklenirken yanlış vergi politikalarının tercih edilmesi durumunda, vergilerin mal ve hizmet fiyatlarına eklenerek tüketicilere yansıtılması halinde artırılan vergiler enflasyonist bir etki de doğurabilmektedir (Uluatam(a): 1981, s.51). Enflasyon vergi ile yakın bir ilişki içerisinde bulunmakta olup literatürde enflasyon vergisi tartışılmaktadır. Teorik açıdan enflasyon vergisi adı altında bir vergi bulunmamakla birlikte pratik açıdan enflasyonunun kamu bütçesine sağladığı gelirler nedeniyle enflasyonun vergi etkisi yerine, enflasyon vergisi gibi adlandırmalar kullanılmaktadır. Vergi gelirleri 1245 yılında akdedilen Magna Carta Libertatum' dan beri birçok ülkede kanunla konulmakta ve alınmaktayken enflasyon için bu durum söz konusu değildir. Ayrıca vergilerin kanunlaşması aşamasında vergide belirlilik ilkesinin gereği olarak verginin yükümlüsü, matrahı, oranı ve diğer unsurlar sarih olarak belirlenmekteyken yine enflasyonda böyle bir belirleme yoktur (Engin, 2000, s.98-101).

Enflasyon, emisyon gelirleri ve vergi matrahlarında yaşanan nominal artışlar nedeniyle kamuya ekstra gelir sağlarken diğer yandan Tanzi etkisiyle de kamu gelirlerinin reel değerini azaltmaktadır. Bunun için vergi sistemlerinde enflasyonun etkilerini azaltıc olarak; endeksleme, yeniden değerleme, geçici vergi ve benzeri gibi çeşitli önlemler geliştirilmiştir. Yine yüksek enflasyonun yaşandığı ekonomilerde kamunun mal ve hizmet alımlarında yaptığı ödemeler ile ürettiği fiyatlandırılabilir mal/hizmet bedellerinin tahsilinde yaşanan gecikmelerde enflasyonun kamu gelir/giderleri üzerindeki etkisi yadsinamayacak derecede önemlidir. 


\title{
EXTENDED ABSTRACT
}

\section{Impact of the Covid-19 Outbreak on Turkey's Tax Revenues}

\author{
* \\ Hamza Erdoğdu- Murat Demir- Rıdvan Önder \\ Harran University - Harran University- Hacı bayram Veli University
}

Background: The World Bank predicts that due to the epidemic that emerged in China at the end of 2019 and affected the whole world, the shrinkage in GDP on a global scale will be approximately $5.2 \%$. The World Bank expresses this economic contraction that emerged in 2020 as the biggest economic recession in the world after 1929. Considering the reasons for the contraction; it is seen that the cessation of many economic activities in order to prevent the spread of the epidemic and the sharp decreases in consumption and investment expenditures are the determinants.

Purpose: This study aims to analyze the epidemic Covid-19, emerging in the People's Republic of China in the last quarter of 2019 and influencing the whole world, effect on tax revenues in Turkey. For this tax revenue of Turkey is explained by a model with macro variables such as economic growth, inflation and interest rates, including a dummy variable to take into account the impact of the economic crisis caused by the Covid-19 pandemic, using monthly data on 2006.M01-2021.M01.

Method: In the study, the effects of economic growth, inflation and interest rates on tax revenues are analyzed using monthly data in the case of Turkey. All series were seasonally adjusted and included in the analysis by taking their logarithms. The standard ARDL model, which reflects the effects of the explanatory variables of economic growth, inflation rate and interest rates, including the dummy variable used in the study, on tax revenues for the short and long term was used. In addition to the standard approach, the non-linear ARDL (NARDL) methodology, which was developed to examine the effects of the possible asymmetric effects of explanatory variables on tax revenues, was also used. 
Findings: In the study, firstly, the correlation matrix between the variables was obtained. Accordingly, it shows that there is a positive relationship between tax revenues and economic growth and inflation variables, and an inverse relationship with interest rates. Afterwards, the unit root tests of the variables were examined and their stationarity levels were determined. Accordingly, while the variables in the study are not stationary at level levels, they become stationary when their first difference is taken.

When it was seen that the necessary conditions for the ARDL methodology were met, the Bounds test was applied. The test results show that there is a cointegration relationship between tax revenues and economic growth, inflation and interest rates in Turkey for the examined period. It has been determined that a $1 \%$ increase in economic growth in the long run will increase tax revenues by approximately $0.65 \%$, and a $1 \%$ increase in inflation will lead to an increase of $1.13 \%$ in tax revenues. However, a $1 \%$ increase in interest rates has been found to reduce tax revenues by $0.07 \%$.

In the study, it was seen that the dummy variable coefficient used to include the effect of the economic crisis caused by the Covid-19 pandemic into the model was negative (-0.067579) and statistically significant at the $1 \%$ significance level.

If the variance decomposition results are to be interpreted as a whole, it is seen that the variable of economic growth explains the variability in tax revenues at a higher rate compared to other variables. This result also supports the results of the NARDL model.

Conclusions : When the results obtained from the study are evaluated together, it is useful to emphasize the following points:

The continuation of the impact of the Covid-19 pandemic in the form of third and fourth waves at the global level and in Turkey as of the date of writing of the article necessitates various social and economic restrictions. This situation means that the economic growth of the countries is realized at low rates and thus the tax revenues decrease. If the effect of the Covid-19 pandemic continues to increase in this way, it can be expected that the dummy variable, which is the carrier of the Covid-19 effect in the regression models, will be statistically significant and its coefficient will increase. 
The importance of sustainable positive growth is undeniable for a developing country like Turkey, which has a young and growing population and wants to raise its living standards to the level of developed countries in every field. The effect of this situation, which will last for many years, will strengthen the hand of the public finance and treasury against all possible economic shocks, by keeping the government's orientation to borrowing and other non-tax alternatives to a minimum in meeting the public financing needs of the state.

\section{Kaynakça/References}

Akar, S. (2013). Vergi gelirlerinin esnekliği ve istikrarı: Merkezi bütçe sınıflandırmasına dayalı ampirik bir analiz. Maliye Dergisi, 165, 27-37.

Akbulut, H. (2017). Enflasyon ve faiz oranlarınn vergi gayreti ile ilişkisi: Türkiye'de uygulanan gelir vergisi için ampirik bir uygulama. Finans Politik \& Ekonomik Yorumlar, 54(630), 55-65.

Akkaya, Ş. (1998).Gelişmekte olan ülkelerdeki vergi sisteminin değerlendirilmesi ve bu ülkelerdeki vergi yapısının kantitatif analizi. İstanbul Üniversitesi İktisat Fakültesi, Maliye Araştırma Merkezi Konferansları, 37, 213-267.

Belinga, V., Benedek, D., Mooij, R. ve Norregaard, J. (2014). Tax Buoyancy in OECD countries. IMF Working Paper, Fiscal Affairs Department, $\mathrm{WP} / 14 / 1101-18$.

Dackehag, M. ve Hansson, Å. (2012). Taxation of income and economic growth: An empirical analysis of 25 Rich OECD Countries. Working Papers, Lund University, Department of Economics, s.6.

Demir, M. ve Sever, E. (2017). Vergi gelirleri ekonomik büyüme ilişkisi: OECD ülkelerine ilişkin panel veri analizi. Aksaray Üniversitesi İktisadi ve İdari Bilimler Fakültesi Dergisi, 9(2), 51-66.

Dickey, D. A. ve Fuller, W.A. (1979). Distribution of the estimators for autoregressive time series with a unit root. J. Amer. Stat. Assoc., 74(366), 427-431.

Ekici, M. S. (2009). Vergi gelirlerini etkileyen ekonomik ve sosyal faktörler. Elektronik Sosyal Bilimler Dergisi, 8(30), 200-223.

Elgin, C, Basbug, G. ve Yalaman, A. (2020). Economic policy responses to a pandemic: developing the Covid-19 economic stimulus index. Covid Economics: Vetted and Real Time Papers, 3, 40-54.

Engin, İ. (2000). Enflasyonun vergi etkisi. Gazi Üniversitesi İIBF Dergisi, 2(2), 98101. 
Ertürk, Atabey, S., Avşar, T. ve Bulut, M. (2009). Türkiye verilerine göre vergi canlılığ1 ve esnekliğinin tahmin edilmesi. Ekonomik Yaklaşım, 20(71), 109119.

Göçer, İ., Mercan, M. ve diğerleri, (2010). Ekonomik büyüme ile vergi gelirleri arasındaki ilişki: Sınır testi yaklaşımı. Dumlupınar Üniversitesi Sosyal Bilimler Dergisi, 28, 97-110.

Greene, William H. (2012). Econometric analysis. Seventh Edition. International Edition, Pearson Education, Prentice Hall.

Gül, E. ve Barış K. (2009). AB ülkeleri ve Türkiye'de vergi gelirleri ile ekonomik büyüme ilişkisi: 1980-2008. Süleyman Demirel Üniversitesi, 1.Uluslararası Davraz Kongresi, Isparta.

Haughton, J. (1998). Estimasting tax buoyancy, elasticity and stability. Eager/PSGE- Excise Project Methodological Note 1, 1-8.

Hepaktan, C. E. ve Çınar, S. (2011). OECD Ülkeleri vergi sistemi esnekliğinin panel eşbütünleşme testleri ile analizi. Sosyal Bilimler Dergisi, IV(2), 133-153.

Kutbay, H. (2019). Vergi gelirlerini etkileyen faktörler: Seçilmiş ülkeler için panel veri analizi. Mehmet Akif Ersoy Üniversitesi İktisadi ve İdari Bilimler Fakültesi Dergisi, 6(3) , 602-617.

Laeven, L. ve F. Valencia, (2013). Systemic banking crises database. IMF Economic Review, 61, 225-270.

Ma, C., Rogers, J. ve Sili Z., (2020). Modern pandemics: Recession and recovery. International Finance Discussion Papers. Washington: Board of Governors of the Federal Reserve System, https://doi.org/10.17016/IFDP.2020.1295.

Mishra, P. K. (2011). The Cointegration and causality between tax revenue and economic growth in India. IASMS Journal of Business Spectrum, 4(2), 124134.

Możdzierz, A. (2017). The impact of changes in indirect tax rates on inflation in selected EU countries. Annales Universitatis Mariae Curie-Skłodowska, Sectio H Oeconomia, 51(4), 257-267.

Muibi, O. S. ve Sinbo, O. M. (2013). Macroeconomic determinants of tax revenue in Nigeria (1970-2011). World Applied Sciences Journal, 28(1), 27-35.

Nalraj, P. (2015). An estimate to tax buoyancy of service tax of union budget of India. International Journal of Creative Research Thoughts, 3(3), 522-525.

Organisation for Economic Co-operation and Development, (2020). Revenue Statistics 2020: Tax Revenue Trends In The OECD, Paris, http://www.oecd.org Organisation for Economic Co-operation and Development, (2020). OECD Data. https://data.oecd.org 
Phillips, P.C. ve Perron, P. (1988). Testing for a unit root in time series regression. Biometrika, 75(2), 335-346.

Shin, Y., Yu, B. ve Greenwood-Nimmo, M. (2014). Modelling asymmetric cointegration and dynamic multipliers in a nonlinear ARDL framework. Festschrift in Honor of Peter Schmidt, Springer, New York, NY, 281-314.

Taha, R., Loganathan, N. ve Sisira R.N. C. (2011). The effect of economic growth on taxation revenue: The case of a newly industrialized country. International Review of Business Research Papers, 7(1), 319-329.

Temiz, D. (2008). Türkiye'de vergi gelirleri ve ekonomik büyüme ilişkisi: 19602006 dönemi. 2. Ulusal İktisat Kongresi, İzmir-Türkiye.

Turhan, S. (2002). İktisadi istikrar ve vergi politikası uygulamasına ilişkin sorunlar. İstanbul Ticaret Üniversitesi Dergisi, 59-86.

Turhan, S. (2020). Vergi teorisi ve politikası. İstanbul: Filiz Kitabevi.

Uluatam(a), Ö. (1981). Enflasyon ve devlet gelirleri(1963-1978). Ankara Üniversitesi Siyasal Bilgiler Fakültesi Yayınları, 462.

Uluatam, Ö. (1990). Enflasyon ve vergileme. VI. Türkiye Maliye Eğitimi Sempozyитu.

Velaj, E. ve Prendi, L. (2014). Tax revenue - the determinant factors - the case of Albania. European Scientific Journal. Special Edition, 1, 526-531.

World Bank, (2020). Global outlook pandemic, recession: the global economy in crisis. Global Economic Prospects, 2020.

\section{Kaynakça Bilgisi / Citation Information}

Erdoğdu, H., Demir, M. ve Önder, R. (2021). Covid-19 salgınının Türkiye' nin vergi gelirleri üzerine etkisi. OPUS-Uluslararası Toplum Araştırmaları Dergisi, 18(43), 6478-6506.

DOI:10.26466//opus.931186. 